\title{
Chemical composition, antioxidant and antimicrobial potential of essential oils from different parts of Daphne mucronata Royle
}

\author{
Iqra Ashraf ${ }^{1}$, Muhammad Zubair ${ }^{1 *}$, Komal Rizwan ${ }^{1,2}$, Nasir Rasool ${ }^{1}$, Muhammad Jamil', Shakeel Ahmad Khan $^{3}$, \\ Rasool Bakhsh Tareen ${ }^{4}$, Viqar Uddin Ahmad ${ }^{5}$, Abid Mahmood ${ }^{6}$, Muhammad Riaz ${ }^{7}$, M. Zia-Ul-Haq ${ }^{8}$ \\ and Hawa ZE Jaafar ${ }^{* *}$
}

\begin{abstract}
This research work was executed to determine chemical composition, anti-oxidant and anti-microbial potential of the essential oils extracted from the leaves and stem of Daphne mucronata Royle. From leaves and stem oils fifty-one different constituents were identified through GC/MS examination. The antioxidant potential evaluated through DPPH free radical scavenging activity and \%-inhibition of peroxidation in linoleic acid system. The stem's essential oil showed the good antioxidant activity as compared to leaves essential oil. Results of Antimicrobial activity revealed that both stem and leaves oils showed strong activity against Candida albicans with large inhibition zone (22.2 \pm 0.01 , $18.9 \pm 0.20 \mathrm{~mm})$ and lowest MIC values $(0.98 \pm 0.005,2.44 \pm 0.002 \mathrm{mg} / \mathrm{mL})$ respectively. Leaves essential was also active against Escherichia coli with inhibition zone of $8.88 \pm 0.01 \mathrm{~mm}$ and MIC values of $11.2 \pm 0.40 \mathrm{mg} / \mathrm{mL}$. These results suggested that the plant's essential oils would be a potential cradle for the natural product based antimicrobial as well as antioxidant agents.
\end{abstract}

Keywords: D. mucronata, Essential oil, Antioxidant, Leaves, Camphor

\section{Background}

Medicinal plants are well-known since beginning of human civilization for welfare of mankind and they dwell an imperative place in the socio-cultural as well as in the health-system of indigenous communities of Pakistan. Plant's essential oils are worthwhile natural-products that are employed as raw materials in various fields, such as cosmetics, fragrances, phyto-therapy, nutrition and spices. Daphne mucronata Royle belongs to the family Thymelaeaceae. Common names of this plant include Kutilal, Nirko, Laighonai (laighuanay), Kheweshk. Leaves of this plant are poisonous and applied as insect repulsive abscesses for sore and glue is used for muscular and

\footnotetext{
*Correspondence: zubairmkn@yahoo.com; hawazej@gmail.com

${ }^{1}$ Department of Chemistry, Government College University,

Faisalabad 38000, Pakistan

${ }^{9}$ Department of Crop Science, Faculty of Agriculture, Universiti Putra

Malaysia, 43400 Serdang, Selangor, Malaysia

Full list of author information is available at the end of the article
}

nerve troubles [1]. Plant poultice is applied for rheumatism and sweeping [2]. The plant has attractive flowers and can be used as decorative plant [3]. The roots and shoots of $D$. mucronata Royle are considered as anthelmintic and employed in treatment of gonorrhea [4]. Fruits are multipurpose so they are used for eating purposes and for treating eye problems, to cure skin, considered as remedy for face freckles, for killing lices, ticks and are also involved in coloring leather $[4,5]$. Wood is used as firewood and used in preparation of gun powder charcoal [6]. The bark is used in turmoil of bone for washing hairs and in folk medicines. Previous study revealed the presence of several phytochemicals, in this specie [7]. To date, there are no previous reports related to Phytochemical composition as well as biological potential of plant Daphne mucronata Royle essential oils. As part of our efforts [8-12] this study is, therefore, reporting for the first time the aerial parts (stem and leaves) essential oil composition, and there biological potential. 


\section{Results and discussion}

Percentage yield and chemical composition of essential oils

The yield of the essential oils (Dry plant samples) obtained from the hydrodistillation of the $D$. mucronata leaves and stem were $5.6 \%$ and $9.5 \% \mathrm{~g} / 100 \mathrm{~g}$ respectively shown in Table 2 . The components were identified in the essential oils with their percentage composition, relative retention time and retention indices (Table 1, Fig. 2). Twenty-seven (27) constituents were identified and quantified in the oil of $D$. mucronata leaves, representing $97.25 \%$ of the total oil. The major components were pentadecane (12.75\%), 2-methyl hexadecane (8.90\%), 7,9-dimethyl hexadecane (8.90\%), tetradecane (7.32\%), 5-Propyl decane (6.16\%), $2,3,5,8$ tetramethyl hexadecane (5.81\%), 2-methyl6-propyl dodecane (5.11\%), 5-methyl tetradecane (5.10\%) (Table 1, Fig. 1). In the oil of D. mucronata stem twenty-seven constituents $(91.2 \%)$ were identified. The major compounds were 11,14,17-eicosatrienoic acid, methyl ester (18.57\%), methyl palmitate (16.0\%), (Z,Z)-9,12-octadecadienoic acid methyl ester (13.99\%), tetratriacontane $(6.65 \%)$, caryophyllene oxide (5.94) (Table 1, Fig. 1). GC/MS spectra of both (stem and leaves) essential oils are presented in Fig. 2. The essential oils consisted of some straight chain alkanes, fatty acids, methyl esters and aromatics, which may be involved in antioxidant and antimicrobial activities.

\section{Antioxidant and antimicrobial potential of essential oils}

Free radicals are highly reactive species which are produced in human body due to various reactions taking place in human body, radiations exposure and environment pollution. These radicals are responsible for damaging human health and cause many diseases. Antioxidants are responsible for scavenging the radicals and convert them to less reactive species. Plants are best natural source of antioxidants. Antioxidant potential of plant $D$. mucronata essential oils was investigated by DPPH scavenging assay and by measuring \% Inhibition of peroxidation in linoleic acid system. The plant oils showed moderate antioxidant activity (Table 2). Stem essential oil proved most active, with an $\mathrm{IC}_{50}$ value of $45.46 \pm 0.04 \mu \mathrm{g} / \mathrm{mL}$, followed by leaves essential oil $\left(\mathrm{IC}_{50}=85.15 \pm 0.31 \mu \mathrm{g} / \mathrm{mL}\right)$. Maximum \% inhibition of peroxidation in linoleic acid system was showed by the stem essential oil $(64.16 \pm 0.93)$ followed by leaves essential oil $(37.57 \pm 0.89)$. So stem essential oil showed maximum antioxidant potential as compared to leaves of plant. When the results of DPPH scavenging activity $\left(\mathrm{IC}_{50}\right)$ and the percent inhibition of peroxidation in linoleic acid system were compared with standard BHT
Table $1 \mathrm{GC} / \mathrm{MS}$ analysis of $D$. mucronata essential oils

\begin{tabular}{|c|c|c|c|}
\hline \multirow{2}{*}{$\begin{array}{l}\text { Retention } \\
\text { indices }\end{array}$} & \multirow[t]{2}{*}{ Compound name } & \multicolumn{2}{|l|}{$\%$ Area } \\
\hline & & Leaves & Stem \\
\hline 716 & Cyclohexyl methane & - & 0.96 \\
\hline 805 & trans-1,2-dimethylcyclohexane & 0.86 & - \\
\hline 820 & 2,2,3,4-Tetramethylpentane & 2.08 & 3.47 \\
\hline 944 & 2,3,3-Trimethyl-octane & 1.24 & - \\
\hline 970 & 5-(1-methylpropyl)-nonane & 3.13 & - \\
\hline 1044 & Camphor & - & 1.27 \\
\hline 1099 & 2,2-dimethyl octanol & 1.26 & - \\
\hline 1114 & 3-Thujanone & - & 0.6 \\
\hline 1138 & trans-5,6-Epoxydecane & 0.84 & - \\
\hline 1175 & 1-Terpinen-4ol & - & 0.31 \\
\hline 1264 & 2-Methyl-6-propyl dodecane & 5.11 & - \\
\hline 1298 & 2,3,5,8-Tetramethyl decane & 5.81 & 0.37 \\
\hline 1322 & 7,9-dimethyl hexadecane & 8.90 & - \\
\hline 1399 & Tetradecane & 7.32 & - \\
\hline 1445 & 2-Bromo dodecane & 1.20 & - \\
\hline 1454 & 5-Methyl tetradecane & 5.10 & - \\
\hline 1500 & Pentadecane & 12.75 & - \\
\hline 1542 & 7-Methyl pentadecane & 1.63 & - \\
\hline 1563 & Caryophyllene oxide & - & 5.94 \\
\hline 1660 & 2,6,10,15-Tetramethyl heptadecane & 2.71 & - \\
\hline 1664 & Ar-tumerone & - & 3.94 \\
\hline 1666 & 2-Methyl hexadecane & 8.90 & - \\
\hline 1686 & (Z)-11-Pentadecenal & 2.88 & - \\
\hline 1719 & 8-Hexyl pentadecane & - & 0.86 \\
\hline 1745 & 8-Methyl heptadecane & - & 0.34 \\
\hline 1800 & 5-Propyl decane & 6.16 & - \\
\hline 1848 & Hexahydrofarnesyl acetone & - & 2.35 \\
\hline 1854 & 5-Methyl octadecane & 1.30 & - \\
\hline 1878 & Methyl palmitate & - & 16.02 \\
\hline 1897 & 7-Hexadecenoic acid, methyl ester, (Z)- & - & 0.31 \\
\hline 1922 & Dibutyl phthalate & 0.86 & - \\
\hline 1974 & Methyl isoheptadecanoate & - & 0.35 \\
\hline 1984 & n-hexadecanoic acid & 1.74 & - \\
\hline 1999 & D-Mannitol, 1-decylsulfonyl- & 2.89 & - \\
\hline 2000 & Eicosane & 2.66 & - \\
\hline 2067 & $\begin{array}{l}\text { (Z,Z)-9,12-octadecadienoic acid methyl } \\
\text { ester }\end{array}$ & - & 13.99 \\
\hline 2100 & Heneicosane & - & 1.50 \\
\hline 2116 & 11,14,17-Eicosatrienoic acid, methyl ester & - & 18.57 \\
\hline 2167 & Decane, 1,1'-oxybis- & 2.52 & - \\
\hline 2190 & Octadecanoic acid, methyl ester & - & 2.36 \\
\hline 2327 & Eicosanoic acid, methyl ester & - & 0.91 \\
\hline 2400 & Tetracosane & - & 0.42 \\
\hline 2413 & Octadecane,3-ethyl-5-(2-ethylbutyl)- & 1.83 & - \\
\hline 2525 & $\begin{array}{l}\text { 1,2- diisooctyl benzenedicarboxylic acid } \\
\text { ester }\end{array}$ & 4.76 & 2.12 \\
\hline 2527 & Behenic acid, methyl ester & - & 1.40 \\
\hline 2714 & Tetracosanoic acid, methy ester & - & 1.44 \\
\hline 2790 & trans-Squalene & - & 2.43 \\
\hline
\end{tabular}


Table 1 (continued)

\begin{tabular}{llll}
\hline $\begin{array}{l}\text { Retention } \\
\text { indices }\end{array}$ & Compound name & \multicolumn{2}{c}{$\%$ Area } \\
\cline { 3 - 4 } & & Leaves & Stem \\
\hline 2908 & Hexacosanoic acid, methyl ester & - & 0.95 \\
3132 & Tocopheryl acetate & 0.81 & - \\
3400 & Tetratriacontane & - & 6.65 \\
3600 & Hexatriacontane & - & 1.16 \\
\hline
\end{tabular}

(Butylated hydroxytoluene), both essential oils showed significantly $(p<0.05)$ less activity.

The reducing potential of plant essential oil (stem, leaves) was investigated at different concentrations (2.5$10 \mathrm{mg} / \mathrm{mL}$ ). The plant (stem, leaves) essential oils satisfied the test of reducing power by giving a linear increase to absorbance with concentration. Leaves essential oil showed maximum reducing power (Fig. 3).

Micro-organisms are responsible for causing damage to human health, spoilage of food and many other problems. Micro-organisms have become drug resistant, so there is need to discover new sources against disease causing micro-organisms. Essential oils and their constituents play key role in inhibiting growth of micro-organisms [13]. The antimicrobial potential of D. mucronata essential oils was determined against various pathogens (Table 3). The results indicated that the stem essential oil sowed potent inhibitory activity against only C. albicans, with the highest inhibition zone $(22.2 \pm 0.01 \mathrm{~mm})$ and the lowest MIC value $(0.98 \pm 0.005 \mathrm{mg} / \mathrm{mL})$. Leaves essential oil was active only against $C$. albicans and $E$. coli. Growth of $C$. albicans was strongly inhibited with large inhibition zone $(18.9 \pm 0.20 \mathrm{~mm})$ followed by MIC value $(2.44 \pm 0.002 \mathrm{mg} / \mathrm{mL})$. Leaves essential oil showed moderate activity against $E$. coli (zone of inhibition $=8.88 \pm 0.01 \mathrm{~mm} ; \mathrm{MIC}=11.2 \pm 0.40$ ). Both essential oils were inactive against Staphylococcus aureus, Nitrospira moscoviensis, Bacillus cereus, Staphylococcus epidermidis, Aspergillus flavus and Aspergillus niger (Table 3). These strains were resistant to $D$. mucronata Royle essential oils. The results of antimicrobial activity were compared to standard drugs Rifampicin and fungone for bacterial and fungal strains respectively. Antimicrobial activity of the some species of Daphne has already been documented in literature [14, 15]. Mikaeili and co-workers [16] reported the anticandidal activity of 1,2-benzenedicarboxylic acid, diisooctyl ester as this compound was

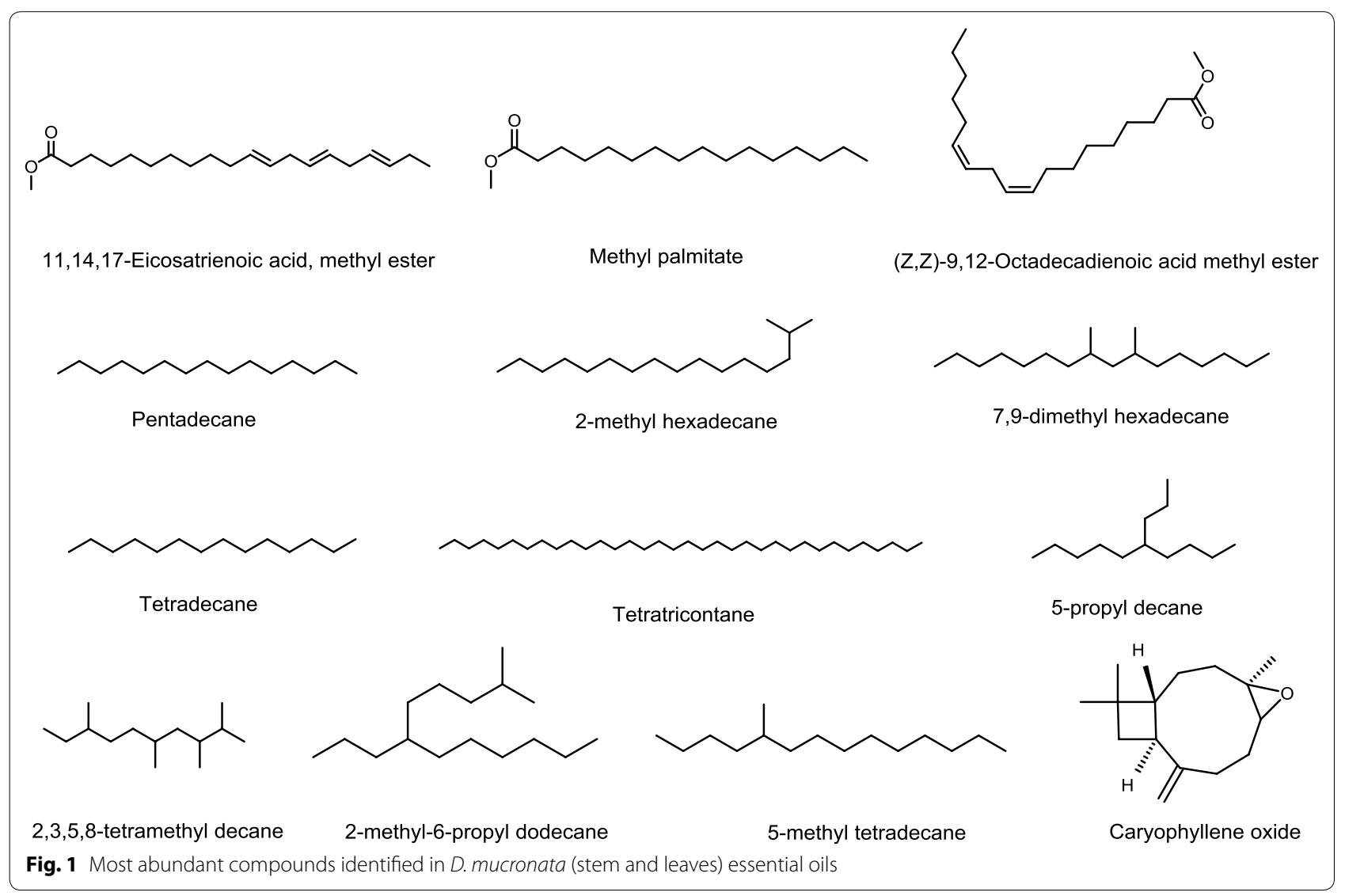




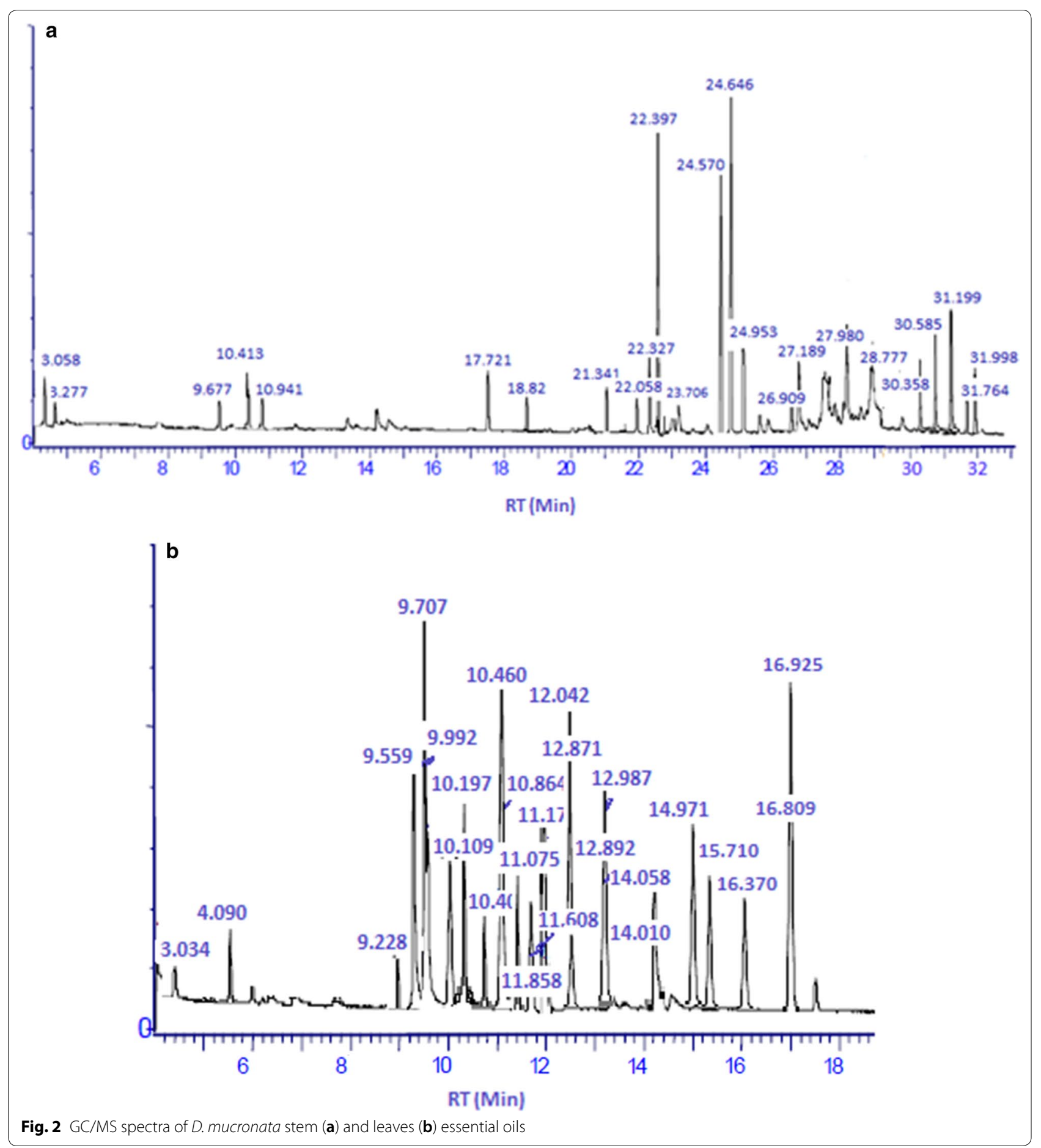

present in both stem and leaves essential oil in good concentration, so essential oils showed potent antimicrobial activity against candida albicans. It has been suggested that the antimicrobial and antioxidant activities of essential oils is attributable to the presence of compounds such as alcohols, aldehydes, alkenes, esters and ethers [17], some of them found in the oils of D. mucronata (Table 1). For instance, the essential oils of $D$. mucronata contain substances as, 3-Thujanone, camphor, Caryophyllene oxide, trans-1,2-dimethylcyclohexane, tetradecane, hexahydrofarnesyl acetone, 5-methyl octadecane found in several vegetal species, which have demonstrated various 
Table $2 \%$ Yield and antioxidant analysis of D. mucronata Royle essential oils

\begin{tabular}{llcc}
\hline Samples, standard compound & \%Yield $\mathbf{~} / \mathbf{1 0 0} \mathbf{~ g}$ & $\begin{array}{l}\text { \% Inhibition of peroxidation in linoleic } \\
\text { acid }\end{array}$ & $\begin{array}{l}\text { DPPH radical } \\
\text { scavenging IC } \\
\mathbf{5 0}\end{array}$ \\
\hline Leaves $/ \mathbf{m L})$
\end{tabular}

Values are mean \pm SD of three separate experiments $(\mathrm{P}<0.05)$ BHT (butylated hydroxytoluene)

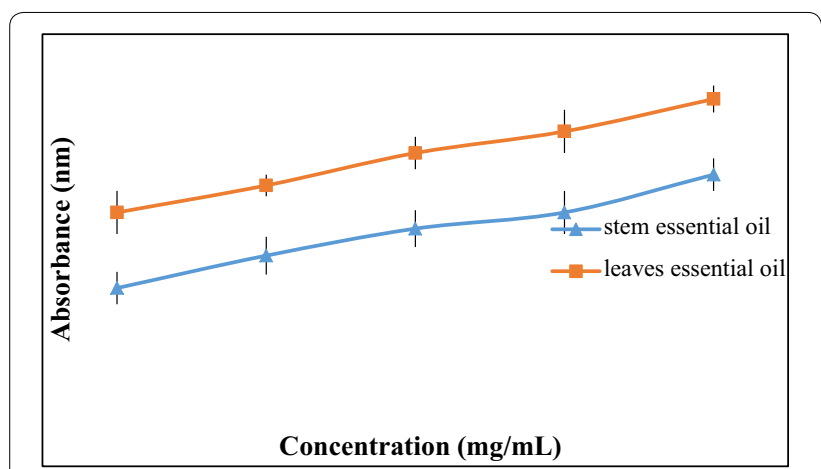

Fig. 3 Reducing potential of D. mucronata Royle essential oils

pharmacological effects [18-21]. It is possible that the antimicrobial and antioxidant activities demonstrated by the essential oils extracted from $D$. mucronata could be attributed to these components. These results are very promising as the oils can be used as a good source of antioxidant and antimicrobial compounds.

\section{Materials and methods}

\section{Plant materials}

The entire plant "D. mucronata Royle" was attained from Quetta, Pakistan. The plant was identified by Prof. Dr.
Rasool Bakhsh Tareen, Botany Department, University of Balochistan, Quetta, Pakistan, where we deposited sample-specimen (Voucher \# DM-RBT-09).

\section{Essential oil extraction}

For the essential oils extraction, $50 \mathrm{~g}$ of each part (stem and leaves) of powdered plant materials dried under the shady place, were hydro distillated by employing a Clevenger-type device for $5 \mathrm{~h}$. Sodium sulphate $\left(\mathrm{Na}_{2} \mathrm{SO}_{4}\right)$ was used for drying the extracted essential oils, then after filtration oils were stored in a vial at $4{ }^{\circ} \mathrm{C}$ till start of further analysis.

\section{GC-MS analysis}

The GC-MS examinations of the essential-oils were done by employing a GCMS-QP2010 (SHIMADZU, Japan). The conditions for GC-MS examinations of essentialoils were: the sample-solution $(1 \mu \mathrm{L} / \mathrm{mg})$ inserted in split-less mode via manually and the time for sampling was $1 \mathrm{~min}$. Then the temperature $200{ }^{\circ} \mathrm{C}$ was established for the injection port. The gas chromatography was fitted out with the column of DB- 5 capillary whose internal diameter, length and film thickness were $0.25 \mathrm{~mm}, 30 \mathrm{~m}$ and $0.25 \mu \mathrm{m}$ respectively. A three step gradient temperature was accomplished for oven: accordingly, $45{ }^{\circ} \mathrm{C}$ for 5 min was set as an initial temperature. Then, initial

Table 3 Antimicrobial activity of $D$. mucronata Royle essential oils

\begin{tabular}{|c|c|c|c|c|c|c|}
\hline \multirow[t]{2}{*}{ Tested microbes } & \multicolumn{2}{|l|}{ Leaves essential oil } & \multicolumn{2}{|l|}{ Stem essential oil } & \multicolumn{2}{|l|}{ Standard drugs } \\
\hline & $\begin{array}{l}\text { Zone of inhibition } \\
(\mathrm{mm})\end{array}$ & $\mathrm{MIC} \mathrm{mg/mL}$ & $\begin{array}{l}\text { Zone of inhibition } \\
(\mathrm{mm})\end{array}$ & $\mathrm{MIC} \mathrm{mg/mL}$ & $\begin{array}{l}\text { Zone of inhibition } \\
(\mathrm{mm})\end{array}$ & $\mathrm{MIC}(\mathrm{mg} / \mathrm{mL})$ \\
\hline A. flavus & - & - & - & - & $19.0 \pm 0.60$ & $0.86 \pm 0.001$ \\
\hline A. niger & - & - & - & - & $20.7 \pm 0.55$ & $0.48 \pm 0.001$ \\
\hline B. cereus & - & - & - & - & $21.7 \pm 0.49$ & $0.97 \pm 0.0003$ \\
\hline C. albicans & $18.9 \pm 0.20$ & $2.44 \pm 0.002$ & $22.2 \pm 0.01$ & $0.98 \pm 0.005$ & $23.8 \pm 0.67$ & $0.25 \pm 0.0001$ \\
\hline E. coli & $8.88 \pm 0.01$ & $11.2 \pm 0.40$ & - & - & $25.26 \pm 0.3$ & $0.46 \pm 0.0002$ \\
\hline N. moscoviensis & - & - & - & - & $22.9 \pm 0.43$ & $0.39 \pm 0.0007$ \\
\hline S. aureus & - & - & - & - & $30.0 \pm 0.32$ & $0.25 \pm 0.0001$ \\
\hline S. epidermidis & - & - & - & - & $23.4 \pm 0.50$ & $0.33 \pm 0.0003$ \\
\hline
\end{tabular}

Values are mean \pm S.D of three separate experiments $(P<0.05)$

Rifampicin and fungone were used as standards for bacterial and fungal strains respectively 
temperature was upraised at a rate of $10{ }^{\circ} \mathrm{C}$ upsurge per min up to $150{ }^{\circ} \mathrm{C}$, trailed by $5{ }^{\circ} \mathrm{C}$ per min upsurge up to $280{ }^{\circ} \mathrm{C}$ and finally, temperature touched to the $325{ }^{\circ} \mathrm{C}$ at $15{ }^{\circ} \mathrm{C}$ per min upsurge and keep it for five min. At that time, the Helium was employed at a flow-rate of $1.1 \mathrm{~mL}$ per min (liner velocity and pressure were $38.2 \mathrm{~cm} / \mathrm{sec}$ and $60 \mathrm{kPa}$ respectively). In a scanning mode, the fragments/ ions were scrutinized over $40-550 \mathrm{~m} / z$. The components were identified and recognized on the bases of their mass spectra comparison with the NIST mass spectral library $[22,23]$. Retention indices was calculated by following given formula:

Retention indices (RI)

$$
\begin{aligned}
= & 100 C_{n}+100\left(C_{n+i}-C_{n}\right) \\
& \times T_{R(x)}-T_{R(n)} \div T_{R(n+i)}-T_{R(n)}
\end{aligned}
$$

$\mathrm{C}_{\mathrm{n}}$ and $\mathrm{C}_{\mathrm{n}+\mathrm{i}}$ represents carbon numbers of carbon standards eluting before and after compounds to be identified.

$T_{R(x)}=$ represents retention time of compounds to be identified

$T_{R(n)}=$ retention time of carbon $\left(C_{n}\right)$

$\mathrm{T}_{\mathrm{R}(\mathrm{n}+\mathrm{i})}=$ retention times of carbon $\left(\mathrm{C}_{\mathrm{n}+\mathrm{i}}\right)$

\section{Antioxidant activity \\ DPPH radical scavenging assay}

The antioxidant propensity of plant essential oils was checked by measuring their ability to scavenge stable DPPH free radical following the standard protocol as reported earlier by Rizwan and co-workers [24] with slight modifications. The $1 \mathrm{~mL}$ of $90 \mu \mathrm{M}$ DPPH solution was mixed with the samples (from 10 to $500 \mu \mathrm{g} \mathrm{mL}^{-1}$ ) and $95 \%$ methanol was used to made the final volume up to $4 \mathrm{~mL}$. The Butylated hydroxyl-toluene (BHT) was served as an external standard. Then the sample incubation was done for $1 \mathrm{~h}$ at the temperature of $\left(25^{\circ} \mathrm{C}\right)$. After that, the absorbance was examined at $515 \mathrm{~nm}$. By the following formula Percent DPPH radical scavenging was calculated:

$$
\text { Radical scavenging }(\%)=100 \times\left(\mathrm{A}_{\text {blank }}-\mathrm{A}_{\text {sample }} / \mathrm{A}_{\text {blank }}\right)
$$

where $A_{\text {blank }}$ is the absorbance of the control (containing all reagents except the test samples), and $\mathrm{A}_{\text {sample }}$ is the absorbance of the test samples. $\mathrm{IC}_{50}$ values, which represented the concentration of samples that caused $50 \%$ scavenging, were calculated from the plot of inhibition percentage against concentration.

\section{Percentage-inhibition of linoleic peroxidation}

Antioxidant potential of $D$. mucronata essential oils was evaluated by measuring percent-inhibition of linoleic peroxidation [12]. The $5 \mathrm{mg}$ of plant's essential oil sample mingled with the $0.13 \mathrm{~mL}$ linoleic acid solution, $10 \mathrm{~mL}$ of $0.2 \mathrm{M}$ sodium phosphate buffer of $\mathrm{pH} \sim 7$, $10 \mathrm{~mL}$ of $99.8 \%$ ethanol, and diluted with distilled water (up to $25 \mathrm{~mL}$ ). Then the resultant reaction mixture was hatched at $40{ }^{\circ} \mathrm{C}$ for $360 \mathrm{~h}$ ( 15 days) and extent of oxidation was examined [15]. After that, sample solution $(0.2 \mathrm{~mL})$, ferrous chloride solution $(0.2 \mathrm{~mL})(20 \mathrm{mM}$ in $3.5 \% \mathrm{HCl} \mathrm{w} / \mathrm{v}), 75 \%$ ethanol $(10 \mathrm{~mL})$, and $30 \%$ ammonium thiocyanate $(0.2 \mathrm{~mL})$ were mixed together consecutively. Finally, the absorbance of reaction mixture was noted at $500 \mathrm{~nm}$ after stirring for $3 \mathrm{~min}$. Experiment was also performed on control, which consist only on linoleic acid without sample. As a positive control, the BHT was employed. By a following equation, Percent-inhibition of linoleic acid peroxidation was determined:

\% Inhibition

$$
\begin{aligned}
= & 100-[(\text { Abs. increase of sample at } 360 \mathrm{~h} / \mathrm{Abs} . \\
& \text { increase of control at } 360 \mathrm{~h}) \times 100]
\end{aligned}
$$

\section{Analysis of reducing power}

At different concentrations (2.5-10 mg), the plant oils were mingled with $1 \%$ potassium ferricyanide $(5 \mathrm{~mL})$ and $5 \mathrm{~mL}$ of sodium phosphate buffer $(0.2 \mathrm{M}, \mathrm{pH}$ 6.6) solution. For $20 \mathrm{~min}$ at $50{ }^{\circ} \mathrm{C}$, the reaction mixture was heated and after that, $10 \%$ of trichloroacetic acid $(5 \mathrm{~mL})$ was mixed with heated reaction mixture. Then the resultant solution was subjected for centrifugation for $10 \mathrm{~min}$ at $5{ }^{\circ} \mathrm{C}$ at the rate of $980 \mathrm{rpm}$. At that time, the $5 \mathrm{~mL}$ of upper layer of reaction mixture was dissolved in $5 \mathrm{~mL}$ of distilled $\mathrm{H}_{2} \mathrm{O}$. As a final point, $1 \mathrm{~mL}$ of $0.1 \%$ freshly prepared $\mathrm{FeCl}_{3}$ solution was added in it. At $700 \mathrm{~nm}$ absorbance was noted and result were obtained in triplicates [12].

\section{Antimicrobial assay Microbes}

Four different bacteriological strains (Bacillus cereus ATCC 14579, Escherichia coli ATCC 25922, Staphylococcus epidermidis ATCC 12229 and Nitrospira moscoviensis locally isolated) and three different fungal strains (Aspergillus niger ATCC 10595, Candida albicans ATCC 10231, Aspergillus flavus ATCC 32612) were used to check the antimicrobial effects of essential oils. For this study, pure microbial organisms were provided by Department of Veterinary Microbiology (DVM) (University of Agriculture Faisalabad (UAF), Pakistan). The nutrient agar was employed to culture bacteriological strains overnight at $37^{\circ} \mathrm{C}$ while potato dextrose agar (PDA) was cast off for the development and culturing of fungal strains at $28^{\circ} \mathrm{C}$. 


\section{Disc diffusion method}

The antimicrobial potential of plant essential oils was determined by Disc Diffusion method [25]. For this, the $6 \mathrm{~mm}$ diameter discs were employed whose soaking was performed with $20 \mathrm{mg} / \mathrm{mL}$ essential oil (100 $\mu \mathrm{L} /$ disc $)$. Moreover, soaked disk were placed on the inoculated agar. Discs without samples were used as negative control. The fungone $(100 \mu \mathrm{L} /$ disc $)$ and Rifmapicin $(100 \mu \mathrm{L} /$ disc) were served as a positive control for fungal and bacteriological strains respectively. The incubation of petridishes for bacteria were performed at $37 \pm 0.1{ }^{\circ} \mathrm{C}$ for $24 \mathrm{~h}$ while for fungi at $28 \pm 0.3{ }^{\circ} \mathrm{C}$ for $48 \mathrm{~h}$. For the results, zones of inhibition (ZOIs) formation were measured on the agar media.

\section{Minimum inhibitory concentration (MIC)}

The resazurin microtitre-plate assay was employed to determine the minimum inhibitory concentration (MICs) of the D. mucronata essential oils [26].

\section{Statistical analysis}

All samples were analyzed in triplicate. Data were analyzed by analysis of variance (ANOVA) using Costat (Version 3.8) statistical software.

\section{Conclusions}

We have investigated essential oils from aerial parts of Daphne mucronata obtained by hydro-distillation process. Fifty-one different compounds were found in stem and leaves essential oils by GC-MS analysis. These compounds made the essential oils very effective in antimicrobial and antioxidant potential. Our study revealed that oils obtained from $D$. mucronata could be a promising source of effective antioxidant and antimicrobial compounds and may play vital role for discovery of new drugs against pathogenic diseases. Both of these essential oils may play an important role in flavoring and cosmetic industry.

\section{Authors' contributions}

IA, MZ, KR, NR and MJ made a significant contribution to Conceptualization, data curation and experimental work. SAK, RBT contributed towards formal analysis. VUA, AM, MR, MZUH and HZEJ contributed to interpretation of data and helped in drafting of manuscript. All authors read and approved the final manuscript.

\footnotetext{
Author details

1 Department of Chemistry, Government College University, Faisalabad 38000, Pakistan. ${ }^{2}$ Department of Chemistry, Government College Women University, Faisalabad, Pakistan. ${ }^{3}$ Department of Chemistry, City University of Hong Kong, 83 Tat Chee Avenue, Kowloon, China. ${ }^{4}$ Department of Botany, University of Balochistan, Quetta, Pakistan. ${ }^{5}$ HEJ Research Institute of Chemistry, International Centre for Chemical and Biological Sciences, University of Karachi, Karachi, Pakistan. ${ }^{6}$ Department of Environmental Sciences and Engineering, Government College University, Faisalabad 38000, Pakistan. ${ }^{7}$ Department of Chemistry, University of Sargodha, Sargodha, Pakistan. ${ }^{8}$ ORIC, Lahore
}

College for Women University, Jail Road, Lahore, Pakistan. ${ }^{9}$ Department of Crop Science, Faculty of Agriculture, Universiti Putra Malaysia, 43400 Serdang, Selangor, Malaysia.

\section{Acknowledgements}

The authors are thankful to Higher Education Commission Pakistan (HEC) for funding through the Research Project No 20-1563/R\&D/09/1582.

\section{Competing interests}

The authors declare that they have no competing interests.

\section{Availability of data and materials}

All the main experimental and characterization data have been presented in the form of tables and figures.

\section{Consent for publication}

We the all authors consent to publication.

Ethics approval and consent to participate

Not applicable.

\section{Funding}

The research was funded by Higher Education Commission (HEC), Pakistan.

\section{Publisher's Note}

Springer Nature remains neutral with regard to jurisdictional claims in published maps and institutional affiliations.

Received: 9 July 2018 Accepted: 21 November 2018

Published online: 17 December 2018

References

1. Audipudi AV, Chakicherla BV (2010) Antioxidative and antimicrobial activity of methanol and chloroform extracts of Gmelina arborea Roxb. Int J Biotechnol Biochem 6:139-144

2. Murad W, Ahmad A, Gilani SA, Khan MA (2011) Indigenous knowledge and folk use of medicinal plants by the tribal communities of Hazar Nao Forest, Malakand District, North Pakistan. J Med Plants Res 5:1072-1086

3. Hamayun M (2007) Traditional uses of some medicinal plants of Swat Valley, Pakistan. Indian J Trad Knowl 6:636-641

4. Khan SM, Ahmad H, Ramzan M, Jan MM (2007) Ethnomedicinal plant resources of Shawar Valley. Pak J Biol Sci 10:1743-1746

5. Haidar A, Qaiser M (2009) The ethnobotany of Chitral valley, Pakistan with particular reference to medicinal plants. Pak J Bot 41(4):2009-2041

6. Khan SW, Khatoon S (2007) Ethnobotanical studies on useful trees and shrubs of Haramosh and Bugrote valleys in Gilgit northern areas of Pakistan. Pak J Bot 39:699-710

7. Rasool MA, Imran M, Nawaz H, Malik A, Kazmi SU (2009) Phytochemical studies on Daphne mucronata. J Chem Soc Pak 31:845-850

8. Rizwan K, Zubair M, Rasool N, Riaz M, Zia-Ul-Haq M, de Feo V (2012) Phytochemical and biological studies of Agave attenuata. Int J Mol Sci 13:6440-6451

9. Bari MN, Zubair M, Rizwan K, Rasool N, Bukhari IH, Akram S, Bokhari TH, Shahid M, Hameed M, Ahmad VU (2012) Biological activities of Opuntia Monacantha cladodes. J Chem Soc Pak 34:990-995

10. Zubair M, Rizwan K, Rashid U, Saeed R, Saeed AA, Rasool N, Riaz M (2017) GC/MS profiling, in vitro antioxidant, antimicrobial and haemolytic activities of Smilax macrophylla leaves. Arab J Chem 9:S1435-S1442

11. Riaz M, Rasool N, Bukhari I, Zubair M, Shahid M, Bokhari T, Gull Y, Rizwan K, lqbal M, Zia-ul-Haq M (2013) Antioxidant studies using Sunflower oil as oxidative substrate and DNA protective assay by Antirrhinum majus. Oxid Comm 36:542-552

12. Ashraf SN, Zubair M, Rizwan K, Tareen RB, Rasool N, Zia-UI-Haq M, Ercisli S (2014) Compositional studies and biological activities of Perovskia abrotanoides Kar. oils. Biol Res 47:1

13. Dhifi W, Bellili S, Jazi S, Bahloul N, MnifW (2016) Essential oils' chemical characterization and investigation of some biological activities: a critical review. Medicines 3:25 
14. Cottigli F, Loy G, Garau D, Floris C, Caus M, Pompei R, Bonsignore L (2001) Antimicrobial evaluation of coumarins and flavonoids from the stems of Daphne gnidium L. Phytomedicine 8:302-305

15. Deiana M, Rosa A, Casu V, Cottiglia F, Bonsignore L, Dessi M (2003) Chemical composition and antioxidant activity of extracts from Daphne gnidium L. J Am Oil Chem Soc 80:65-70

16. Mikaeili A, Karimi I, Shamspur T, Gholamine B, Modaresi M, Khanlari A (2012) Anti-candidal activity of Astragalus verus in the in vitro and in vivo guinea pig models of cutaneous and systemic candidiasis. Revista Brasileira de Farmacognosia 22:1035-1043

17. Knobloch K, Pauli A, Iberl B, Weigand H, Weis N (1989) Antibacterial and antifungal properties of essential oil components. J Essent Oil Res 1:119-128

18. Laciar A, Vaca Ruiz M, Carrizo Flores R, Saad J (2009) Actividad antibacteriana y antioxidante del aceite esencial extraído de Artemisia echegarayi Hieron (Asteraceae). Revista argentina de microbiología 41:226-231

19. Chavan M, Wakte P, Shinde D (2010) Analgesic and anti-inflammatory activity of Caryophyllene oxide from Annona squamosa L. bark. Phytomedicine 17:149-151

20. Radulovic N, Dekic M, Stojanovic-radic Z, Palic R (2011) Chemical composition and antimicrobial activity of the essential oils of Geranium columbinum L. and G. lucidum L. (Geraniaceae). Turk J Chem 35:499-512
21. Delazar A, Nazifi E, Movafeghi A, Nahar L, Nazemiyeh H, Moghadam S, Asnaashari S, Sarker S (2009) GC-MS analysis of Ornithogalum procerum. Daru. 17

22. Masada Y. Analysis of essential oils by gas chromatography and mass spectrometry. 1976

23. NIST Mass Spectral Library (2002) http://www.sisweb.com/software/ms/ nist.htm. Accessed on 23 May 2002

24. Rizwan K, Zubair M, Rasool N, Mahmood T, Ayub K, Alitheen NB, Aziz MNM, Akhtar MN, Bukhary SM, Ahmad VU (2018) Palladium (0) catalyzed Suzuki cross-coupling reaction of 2,5-dibromo-3-methylthiophene: selectivity, characterization, DFT studies and their biological evaluations. Chem Cent J 12:49

25. Wayne $P$ (2002) National committee for clinical laboratory standards. Performance standards for antimicrobial disc susceptibility testing

26. Sarker SD, Nahar L, Kumarasamy Y (2007) Microtitre plate-based antibacterial assay incorporating resazurin as an indicator of cell growth, and its application in the in vitro antibacterial screening of phytochemicals. Methods 42:321-324
Ready to submit your research? Choose BMC and benefit from:

- fast, convenient online submission

- thorough peer review by experienced researchers in your field

- rapid publication on acceptance

- support for research data, including large and complex data types

- gold Open Access which fosters wider collaboration and increased citations

- maximum visibility for your research: over 100M website views per year

At BMC, research is always in progress.

Learn more biomedcentral.com/submissions 